\title{
Diffusion of Innovation and the Technology Adoption Curve: Where Are We? The Zimbabwean Experience
}

\author{
Cinderella Dube ${ }^{1}$, Victor Gumbo ${ }^{2}$ \\ ${ }^{1}$ Research and Innovation Office, National University of Science and Technology, Bulawayo, Zimbabwe \\ ${ }^{2}$ Department of Mathematics, Faculty of Science, University of Botswana, Gaborone, Botswana \\ Correspondence: Cinderella Dube, Research and Innovation Office, National University of Science and Technology, \\ Bulawayo, Zimbabwe.
}

Received: May 4, 2017

doi:10.11114/bms.v3i3.2500
Accepted: June 11, $2017 \quad$ Online Published: June 20, 2017

URL: https://doi.org/10.11114/bms.v3i3.2500

\begin{abstract}
The introduction of the Internet has led to the development of new technologies and applications that have been adopted by organisations and their users to enable them to survive in this age of technology. Online technologies have penetrated Zimbabwe, particularly in the retail industry, however, little research has been done to link the research results to theory particularly the technology adoption theories. Therefore the objective of this study was to explore the current extent of adoption of online transaction platforms in the retail industry in Zimbabwe. Furthermore, this paper purposed to determine the extent of this adoption on the Technology Adoption Curve. The online transaction platforms studied were Internet banking, Automated Teller Machines, Mobile banking, Point of Sale and Mobile money. The study took a mixed method approach where both qualitative and quantitative strategies were used. A three-sample dataset comprising of 268 bank and supermarket customers, 56 bank managers and 31 supermarket managers was used. The resultant adoption rates were plotted on Moore's Technology Adoption Curve. The results indicated that although the retail industry had made great strides to adopt online technology platforms, but the adoption by customers was relatively low at a market penetration of $14.5 \%$. The study thus concluded that Zimbabwe's online technologies were in their infancy stage on the maturity model adoption curve and were inside Moore's chasm on the technology adoption curve. The study recommended to customers to use the adopted online technologies in order to keep abreast with the digital era. On the other hand, banks and supermarkets were urged to devise marketing strategies in an effort to cross the chasm in the Technology Adoption Curve.
\end{abstract}

Keywords: technology adoption curve, internet banking, automated teller machines, mobile banking, point of sale, mobile money

\section{Introduction}

Following the adoption of a multi-currency financial system in January 2009, Zimbabwe has experienced a considerable economic recovery where the annual inflation rate had fallen considerably (Chikoko \& Mangwendeza, 2012). However, despite these achievements, the economy is still facing some challenges which are a reflection of the macro-economic constraints in the country. Some of the challenges include the liquidity crunch, lack of capital inflow, lack of production in the country as well as the high cost of doing business. The liquidity crisis is characterised by shortages of cash, high cost of finance and the fact that money in circulation is too limited to meet the demands of an economy that is struggling to strive (Confederation of Zimbabwean Industries Report, 2014).

In light of the liquidity challenges, in his Monetary Policy Statement, the Governor of the Reserve Bank of Zimbabwe (RBZ) proposed the introduction of a robust Information Communication Technology (ICT) system as one of the major measures to curb the challenges bedevilling the country. He emphasised that ICT promotes improvements in innovation and productivity which are central to the economic performance of many countries and could set the country on the road to economic recovery, sustainable growth and reaching its vision of being a cashless society by 2020. Therefore a discrepancy (the gap) lies between the desired vision (being cashless by 2020) and the current state of affairs (liquidity challenges) where people are not banking their money (Dhliwayo, 2014). Therefore, in an endeavour to promote a cashless society, banks, retailers and utility service providers were urged to adopt measures that promote use of online transaction technologies which enhance online transactions rather than cash transactions (Mangudya, 2014; Tsokota \& von Solms, 2013). 
Research on diffusion of innovations and technology adoption in Zimbabwe indicates that most research has concentrated on merely revealing the extent of adoption and use. Examples include: Dube, Chitura and Runyowa (2009) who studied adoption and use of Internet Banking; Dube, Njanike, Manomano and Chiriseri (2011) who studied the adoption and use of SMS/Mobile banking services; Dube and Gumbo (2017) who studied ICTs in Supermarkets; Mudzingwa and Kabote (2014) who explored the adoption of in the beauty therapy industry and Makiwa and Steyn (2016) who looked into ICT adoption and use in small to medium enterprises. On the other hand, Bara (2016) did an external factor analysis on diffusion and adoption of bank financial innovation in Zimbabwe. Studies that leaned on the diffusion of innovation theories included one done by Kabanda (2014) who studied technology affordances and diffusion for mobile connectivity and applications in Zimbabwean schools. Kabanda concluded that the costs for bandwidth per month are a major obstacle to the fast diffusion of mobile technology and e-learning in Zimbabwe.

In terms of positions, the African Business Panel revealed that Zimbabwe was $10^{\text {th }}$ position on the list of the technologically developed countries in Africa (Muza, 2013). However, little or no attempts have been made to relate the findings of adoption of these technologies on the technology adoption curve in Zimbabwe. Hence a gap exists where results are not explicitly related to the existing theories. Therefore the objectives of the study were to explore the adoption of online technologies in the retail industry in Zimbabwe and to plot the position of the results on Roger's Innovation Adoption Categories and Moore's Adoption Curve. In this study, the retail industry entailed commercial banks and grocery supermarkets in Zimbabwe.

\section{Literature Review}

\subsection{Diffusion and Adoption of Innovation}

A technology is defined as the development and application of tools, machines, materials and processes that help in solving human problems whereas an innovation is often taken to be synonymous with technology except that the innovation has overtones of newness, originality or inventive ideas (Rogers, 2003; Reisman, 2006). In line with Rogers (2003) and Reisman (2006), technology and innovation were taken to be synonymous in this paper. For Rogers (2003), adoption is a decision of full use of an innovation as the best course of action available and rejection is a decision not to adopt an innovation. On the other hand, Rogers (2003) defines diffusion as the process in which an innovation is communicated thorough certain channels over time among members of a social system. Therefore, the adoption/diffusion rate is the relative speed with which an innovation is adopted by members of a social system and is generally measured by the number of individuals who adopt the innovation in a specified period, such as each year. Thus the rate of adoption is a numerical indicator of the steepness of the adoption curve for an innovation (Rogers, 1995). Hence in this study, diffusion of innovation is taken to be the rate at which online technologies have been adopted and the rate at which this adoption has spread throughout the retail industry in Zimbabwe.

\subsection{The Retail Industry}

In this paper, the retail industry refers to the banking industry and supermarkets. Banks provide a wide range of financial services to all sectors of the economy and are governed by the Central Bank of a country. The major functions of banks include accepting deposits, money transfers, advancing loans, payment of customers' bills and other utility functions (Goyal \& Joshi, 2011). On the other hand, supermarkets are businesses that bring together a wide range of goods including food, beverages, over-the counter medicines, detergents, and electrical and non-electrical home and garden goods to a central place where primarily local residents periodically replenish their stock of household products (Steeneken \& Ackley, 2012). Banks and supermarkets were studied together because online transaction platforms from banks are mostly used in conjunction with those in supermarkets as buying groceries is the most likely activity that most people do on a regular basis.

\subsection{Online Transaction Platforms}

In this study, a platform is defined as the basic hardware (computer) and software (operating system) on which online transaction processing can be run. Online Transaction Processing (OLTP) applications are client/server applications that give online users direct access to services and information (Meerapur, 2014). In a banking environment, OLTP entails requesting and receiving money or data from a class of software programs capable of supporting transaction-oriented applications on the Internet (Gilbert and Hewitt, 2013). Therefore, online transactions are password-protected transactions that require a password to authorise the transfer of funds and banking information between the customer and the retailer (Meerapur, 2014). The online transaction platforms studied in this paper were Internet banking, Automated Teller Machines, Mobile banking, Point of Sale and Mobile money.

In this paper, Internet banking is defined as banking done electronically through the bank's website without the intervention of any banking personnel, through one's Personal Computer (PC) or other devices that can access the website through the Internet. In other spheres, Internet banking is synonymous to online banking, e-banking and PC 
banking (Baten \& Kamil, 2010; Dube, Chitura, \& Runyowa, 2009). Internet banking enables bank customers to transfer funds, pay bills in real time and access general information on bank products and services through the use of the bank's website (Hadadi, Otaif, Faqihi, \& Al-ahmadi, 2006). Automated Teller Machines are defined as electromechanical devices that permit authorised users to use machine-readable plastic cards (which are magnetically encoded), and a personal identification number to withdraw cash from their accounts and/or access other services, such as balance enquiries and transfer of funds in real time (Hossain \& Bari, 2006). In this case, the ATM systems are connected to the bank's systems for the retrieval of money and information. Mobile banking is defined as a service that enables customers to access their bank accounts' information, transfer funds or pay bills in real time through their cell phones via a mobile network (Rahmani, Tahvildari, Honarmand, Yousefi, \& Daghighi, 2012). In this case, the bank and the mobile network company get into a partnership and work together to enable Mobile banking transactions. Mobile banking is also referred to as SMS banking and hence in this study Mobile banking and SMS Banking will be taken as synonymous (Dube, Njanike, Manomano \& Chiriseri, 2011).

A Point of Sale (POS) is the point at which a customer makes a payment to the merchant in exchange for goods or services (Bernardo, 2013). In Zimbabwe, using POS to buy groceries is made convenient by the use of the ZimSwitch platform where customers can access their bank accounts for paying groceries through a single point if their bank has partnered with ZimSwitch (Dube \& Gumbo, 2017). ZimSwitch is an online transacting company owned by ZimSwitch Technologies and is the sole national electronic funds switch for Zimbabwe (ZimSwitch Technologies: 2013). Therefore, bank and supermarket customers can use the ATM (through ZimSwith), Internet banking and Mobile banking to buy groceries at the POS system in supermarkets. Mobile money is defined by Ernst and Young (2009) as a service that allows electronic money transfer via a mobile phone. Mobile money is cash-based in that the user needs to deposit money into their account before using it. In this study, on-site person-to-business mobile money transfers were considered (Ernst \& Young, 2009). For a mobile money transaction to take place, there is need for collaboration between the Mobile Network Operator (MNO), Mobile Money Operator (MMO), the supermarket and the customer (Jenkins, 2008). In this respect, the mobile money transfer is initiated by the customer and the money transfer is acknowledged by the supermarket's till operator. In Zimbabwe, the major MNOs are NetOne, Telecel Zimbabwe and Econet Wireless Zimbabwe. They all use pre-paid tariffs. By the end of 2014, the estimated mobile penetration had reached 128\% (Lancaster and Lange: 2015). The MNOs also own the MMOs. By mid-2014, Econet's Ecocash had 3.5 million subscribers translating to $81 \%$ of the market share, Telecel's Telecash had over 600000 subscribers $(14 \%$ of the market share) and NetOne's OneWallet had 200000 subscribers translating to 5\% of the market share (Kabweza, 2014).

\subsection{Theoretical Frameworks}

The Diffusion of Innovation Theories were first discussed historically in 1903 by the French sociologist Gabriel Tarde who plotted the original S-shaped diffusion curve. Ryan and Gross in 1943 introduced the adopter categories that were later popularised by Everett Rogers in 1995 (Rogers 1995, Kaminski, 2011). Later, Moore adapted Roger's Technology Adoption Categories and the Technology Adoption Curve in 1991 (Moore, 1991). These theories were chosen for this study because they relate to the study in that diffusion of innovation explains and determines the rate of adoption of technology in a society. Therefore this study sought to find out at what stage Zimbabwe is on the technology Adoption Curve with respect to online transaction platforms in the retail industry in Zimbabwe.

\subsubsection{The Diffusion of Innovation Process}

Diffusion is the process by which an (i) innovation is (ii) communicated through certain channels over (iii) time taken by members of a (iv) society as shown in Figure 1 (Rogers, 1995). The innovation is the technology that is perceived as new by an individual or organisation. Communication channels refer to the ways in which the information about the innovation flows from the source to the receiver (for example, social media, mass media and interpersonal communication) whereas time refers to the rate of adoption or the time taken by different individuals to adopt the innovation. The social system is a set of interrelated units engaged in joint problem solving to accomplish a common goal. The social system is influenced by the societal norms, tolerance of deviance and its integration as shown in Figure 1. The rate of adoption also depends on the characteristics of the adopter, social characteristics and perceived need for the innovation (Rogers, 1995).

The innovation decision process was composed of 5 stages, namely the knowledge, persuasion, decision, implementation and the confirmation stages as shown in Figure 1. At the knowledge stage the individual learns about the existence of the innovation. This stage includes becoming aware of the innovation through communication via the media and interpersonal interactions. The individual also learns how to use the innovation correctly and the functioning principles describing how and why the innovation works.

At the persuasion stage, the individual/organisation develops an opinion (either positive or negative attitude) about the innovation through subjective evaluations of others like colleagues and peers (social reinforcement). Persuasion is also 
determined by the attributes/characteristics of the innovation, namely; relative advantage, compatibility, complexity, triability and observability. Relative advantage is the degree to which an innovation is perceived as being better than the idea it supersedes and compatibility is the degree to which an innovation is perceived as consistent with the existing values, past experiences and needs of potential adopters. On the other hand, complexity refers the degree to which an innovation is perceived as relatively difficult to understand and use whereas triability refers to the degree to which an innovation may be experimented with on a limited/ test basis. Observability is the degree to which the results of an innovation are visible to others (Rogers, 1995).

At the decision stage, the individual/organisation chooses to either adopt or reject the innovation. In this case, adoption refers to full use of an innovation as the best course of action available and rejection means not to adopt the innovation (Rogers, 1995). According to Rogers there are two types of adoption, that is, continued adoption or active acceptance where there is continued and sustained use and discontinuance or passive acceptance where the innovation is initially accepted and then discontinued. Rogers also identified two types of rejection, that is, later adoption or active rejection which is rejecting an innovation but eventually adopting it later and continued rejection or passive rejection which is straight non-adoption where the individual does not think about adopting the innovation at all (Rogers, 1995; Nabih, Bloem \& Poiesz, 1997).

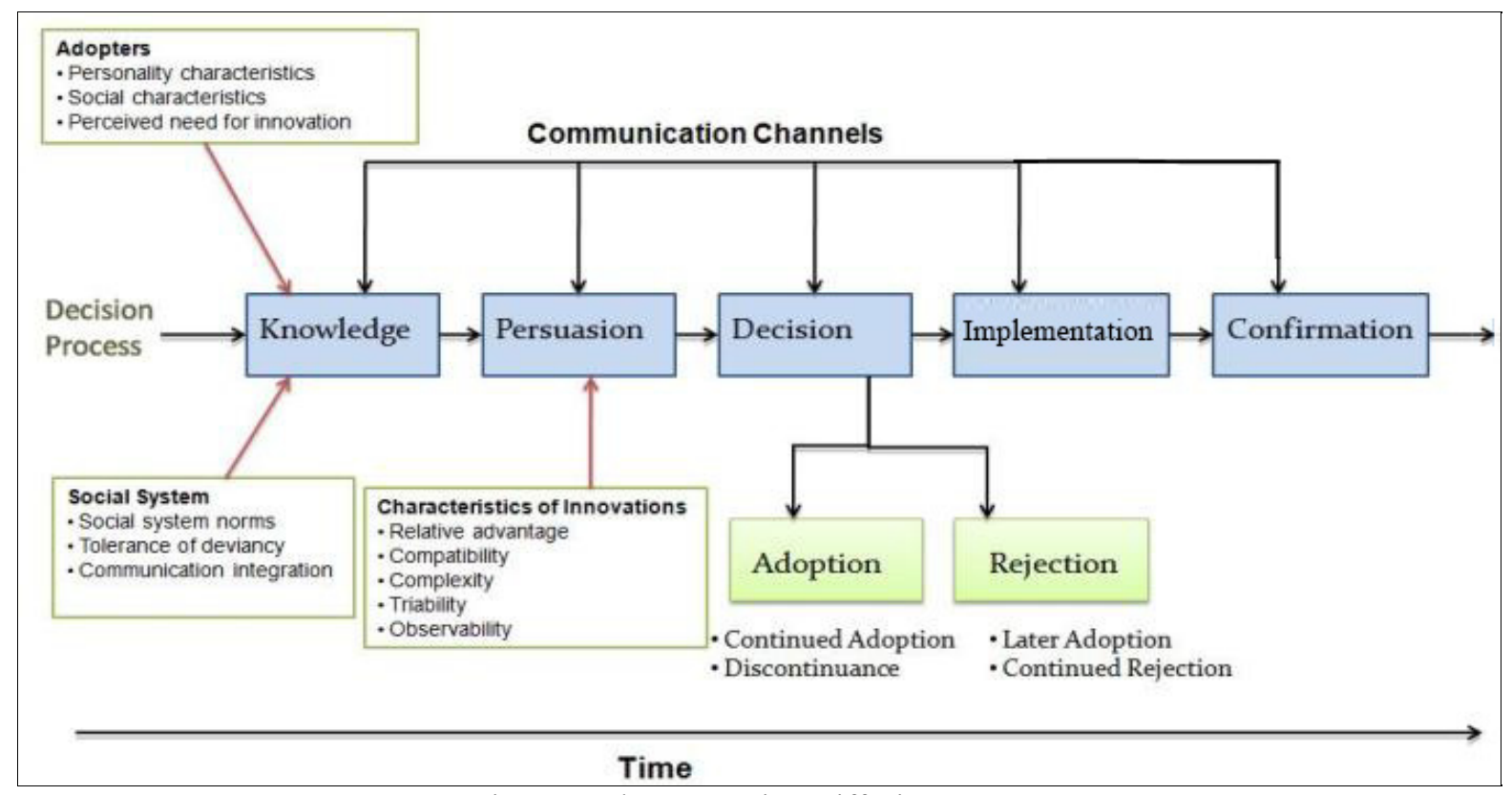

Figure 1. The Innovation Diffusion Process

Source: Rogers (2003) and Chang (2010)

At the implementation stage, mental information processing and decision making come to an end, but the behavioural change begins and the innovation is put into practice (Rogers, 2003). At the confirmation stage the individual/organisation looks for support for their decision. The adopter keeps evaluating the results of their decision and if the level of satisfaction is significant enough and the level of support is high, the use of the innovation will continue. However, if the level of satisfaction is low and there is inadequate support, it is possible that rejection occurs after adoption as shown in Figure 1(Rogers, 1995).

\subsubsection{Roger's Adopter Categories}

Adopter categories are the classifications of the members of a social system on the basis of innovativeness. In this case, adoption refers to continuous use. Therefore, incomplete adoption and non-adoption are not part of this theory. The rate of adoption is measured by the relative length of time required for a certain percentage of the members of a system to adopt an innovation (Rogers, 1995). Rogers (1995) referred to Innovators, Early Adopters, Early Majority, Late Majority and Laggards as innovation categories as shown in Figure 2. In Figure 2 the gentle bell-shaped curve represents the groups of consumers adopting a new technology and the S-curve represents the market share which reaches $100 \%$ following complete adoption. This is the point of market saturation (Rogers, 1995).

In Figure 2, innovators form $2.5 \%$ of the system. Innovators are venturesome and willing to experience new ideas. They are youngest in age, have the highest social class, have great financial lucidity, are very social and have the closest contact to scientific sources and interaction with other innovators. Innovators are risk tolerant, are prepared to cope with 
unprofitable and unsuccessful innovations, and have a certain level of uncertainty about the innovation. Their good financial resources help absorb these failures. They expect the going to be tough and some argue that they even like it that way. Therefore, innovators are the gatekeepers bringing the innovation in from outside of the system. They are technically savvy and have deep application domain expertise (Rogers, 1995).

Early adopters form $13.5 \%$ of the system. They are also techno-savvy, young in age, have a higher social status, financially lucid, advanced in education, and are more socially forward than late early majority. However, they do not have the same drive "to be first and be bloody to prove it" that innovators seem to enjoy. This is because early adopters are more limited because they hold leadership roles (highest opinion leadership) in the social system and other members of the society come to them to get advice or information about the innovation. Thus, as role models, their adoption of an innovation decreases uncertainty about the innovation in the diffusion process. Therefore early adopters put their stamp of approval on a new idea by adopting it. Early adopters have stronger expectations for usability and user assistance than innovators do (Rogers, 1995).

Early majority form $34 \%$ of the system. They have above average social status and have an average amount of knowledge on technology and have even stronger expectations for usability than the innovators and early adopters. The early majority have a good interaction with other members of the social system, but they do not have the leadership role that early adopters have. However, their interpersonal networks are still important in the innovation-diffusion process. The early majority are deliberate in adopting an innovation and they are neither the first nor the last to adopt it. Thus, their innovation decision usually takes more time than it takes innovators and early adopters (Rogers, 1995).

Like the early majority, late majority also form $34 \%$ of the system. They have below average social status, very little financial lucidity and have very little opinion leadership. They might be missing some technical concepts that the product's use requires and they have high expectations for usability and user assistance. They are sceptical about the innovation and its outcomes, its economic necessity and therefore will wait until most of their peers adopt the innovation. To reduce the uncertainty of the innovation, interpersonal networks of close peers persuade the late majority to adopt it, then, they feel that it is safe to adopt (Rogers, 1995).

Laggards form $16 \%$ of the society in question. They have the lowest social status as well as the lowest financial fluidity. They are the oldest of all other adopters, with very little to no opinion leadership. These individuals usually have a dislike to change and change-agents and by the time the laggards start to use the product, the documentation should be robust. Laggards have a traditional view and they are more sceptical about innovations and change than the late majority. As the most localised group of the social system, their interpersonal networks mainly comprise of family and close friends. Due to the limited resources and the lack of awareness or knowledge of innovations, they first want to make sure that an innovation works before they adopt. Thus, laggards tend to decide after looking at whether the innovation is successfully adopted by other members of the social system in the past. Due to all these characteristics, the laggards' innovation-decision period is relatively long (Rogers, 1995). 


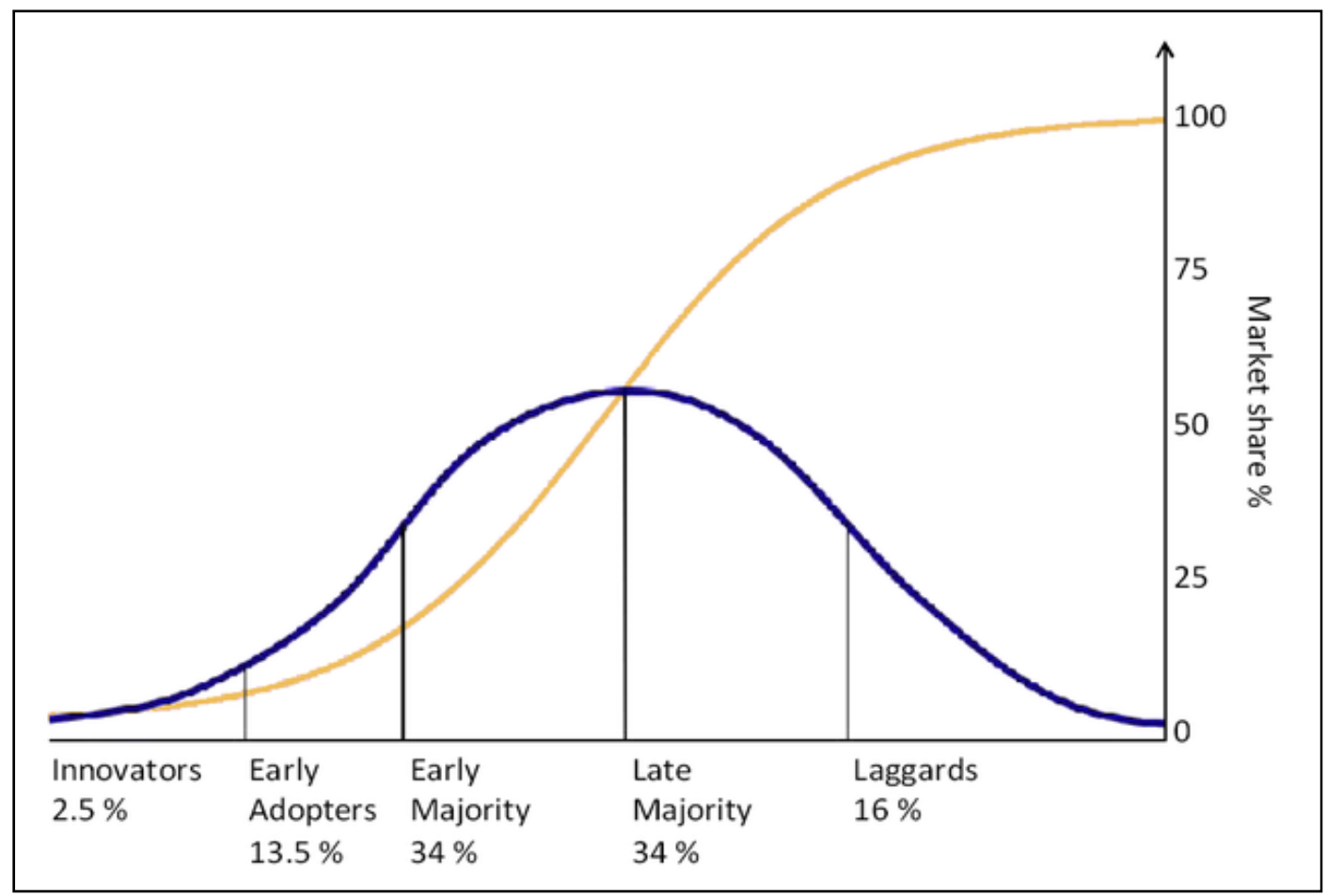

Figure 2. Rogers' Adopter Categories

Source: Rogers (1995), Moore (2015) and Sahin (2006)

\subsubsection{Moore's Technology Adoption Curve}

Moore's Technology Adoption Curve was adapted from Roger's Adoption Categories. Moore substituted Rogers Adoption Stages with new stages, namely, Technology Enthusiasts at the beginning of the curve (invasion stage), Visionaries, Pragmatists, Conservatives and Skeptics (at the tail-end of the curve) respectively (Moore 1991, Martinez, 2010). According to the technology adoption curve technology enthusiasts, like innovators, embrace things immediately because they are attracted to disruptive innovation per se, they want to try out new things and see how they work. Visionaries (early adopters) look to leapfrog their competition by being the first to leverage the new power. They are willing to take extra risks to get a major advantage. The pragmatists (early majority) are interested in the productivity improvements being promised but want to wait until the innovation is sufficiently mature so that it will work reliably without a lot of handholding. They look to each other to get the signal of when it is safe to jump on the bandwagon. The conservatives (late majority) do not like disruption at all and really need to see it thoroughly domesticated and significantly cost reduced before they consider adopting a new technology and the skeptics (laggards) simply want to have as little to do with disruptive innovations as possible (Moore, 1991; May, 2014).

\subsubsection{The Chasm}

Moore (2003) found that there is a psychological gap between 'Early markets' and the 'Mainstream markets', what he calls the chasm (Figure 3). He argues that the customers in the first group are visionaries, and the latter are pragmatists. Visionaries want to be the first to try a new technology. They would not mind to test the technology as long as it is promising and innovative. Pragmatists only want to engage, when it has been tried in order to eliminate risks (Martinez, 2010). Moore explains that the chasm model represents a pattern in technology adoption that is based on the tendency of pragmatic customers and organisations to adopt new technology when they see other people like them doing the same. He goes on to say that the tendency is very deep-rooted and persistent (Martinez, 2010).

According to Moore (1991), when a new product approaches the chasm, it normally is about $80 \%$ of what the complete finished product would look like and that is acceptable for visionaries, but pragmatists will never be comfortable with it. Pragmatists will not accept less than a $100 \%$ finished product. According to Moore, a 'Chasm Crisis' is a series of bad decisions and actions caused by not reaching revenues, targets and other commitments. Moore states that many technologies had failed to cross the chasm because of loss of marketing focus. 


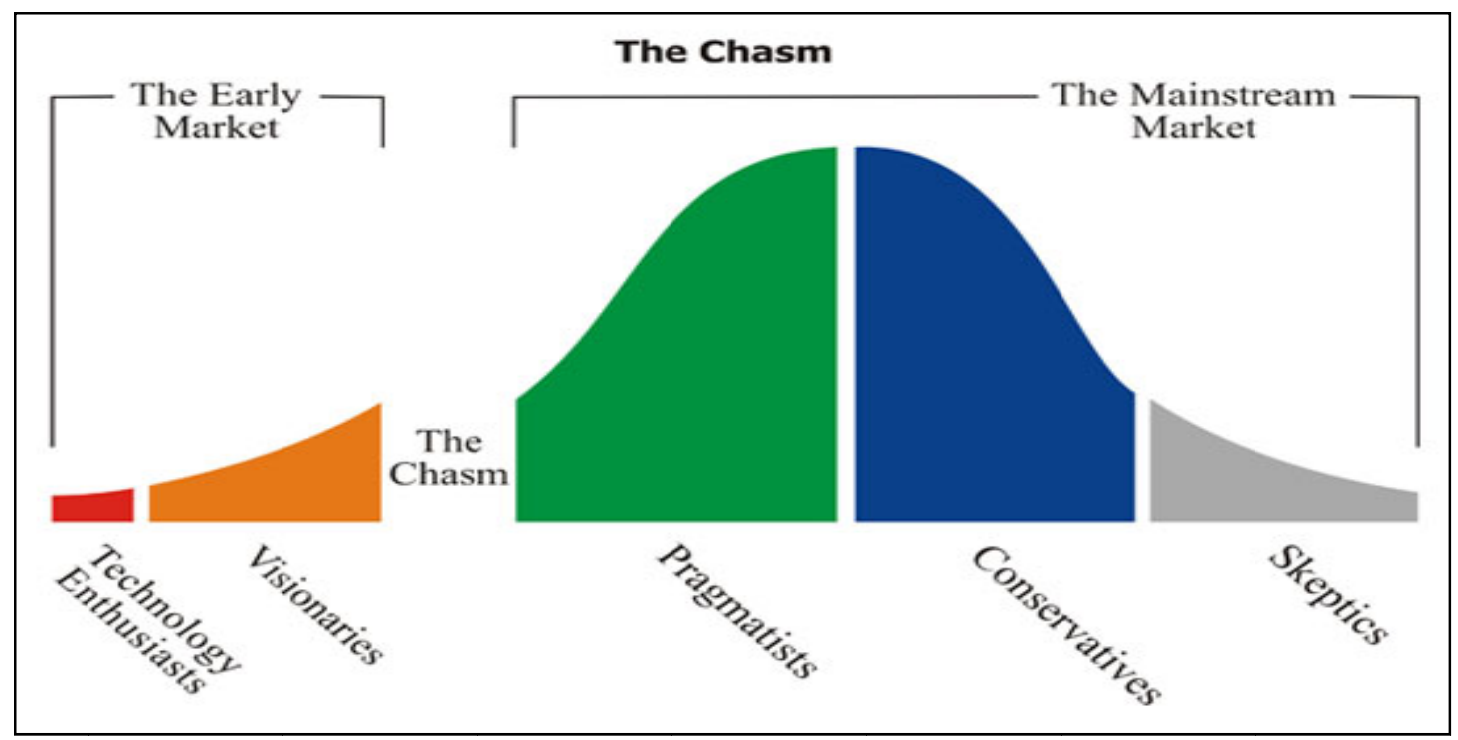

Figure 3. Moore's Technology Adoption Cycle

Source: Martinez (2010)

\subsubsection{The Maturity Model Adoption Curve}

In Figure 4, Moore's adoption curve is likened to the maturity stages of a human being where an innovation grows in its adoption by society. Unlike Roger's technology adopter categories and Moore's technology adoption cycle, which have 5 stages, the maturity adoption curve has 6 stages (Eckerson, 2009). At the prenatal stage only the innovators or the technology enthusiasts accept and use it. At Stage 2 (infant), it is adopted by early adopters or visionaries. Stage 3 (child) is when the innovation is adopted by the early majority or the pragmatists and at stage 4 (teenager), it is adopted by the late majority or conservatives. The innovation is accepted by the adult (laggards or skeptics) at stage 5. At the sixth stage (sage), the innovation is fully adopted by the society and there is little need for marketing it as it drives the market. In most cases, at this stage, marketing efforts would have shifted from it and they would be focused on new products coming into the market at the prenatal stage (Eckerson, 2009).

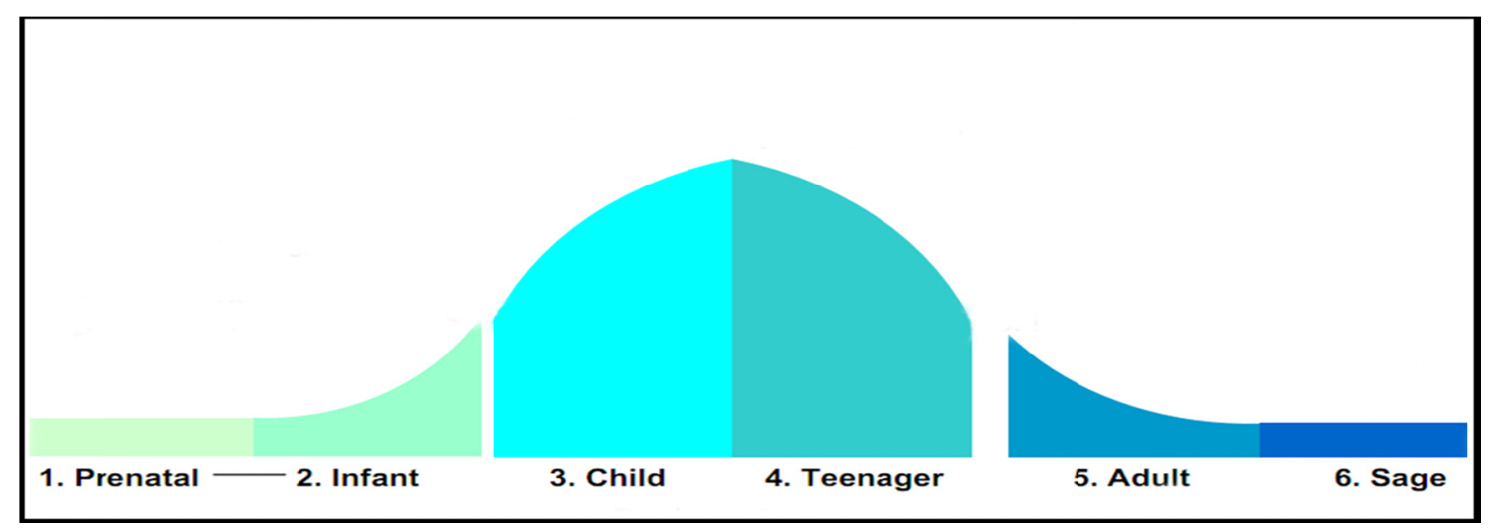

Figure 4. The Maturity Model Adoption Curve

Source: Eckerson (2009)

\subsubsection{Position of the Chasm on the Technology Adoption Curve}

Johnston (2011) extended Roger and Moore's Adoption Models by plotting the position of the chasm on the technology adoption curve with respect to market share percentages on the S-curve as shown in Figure 5. According to Johnston (2011), the chasm exists at 16\% market penetration but can occur anywhere between $10 \%$ and $40 \%$ market penetration as shown in Figure 5. 


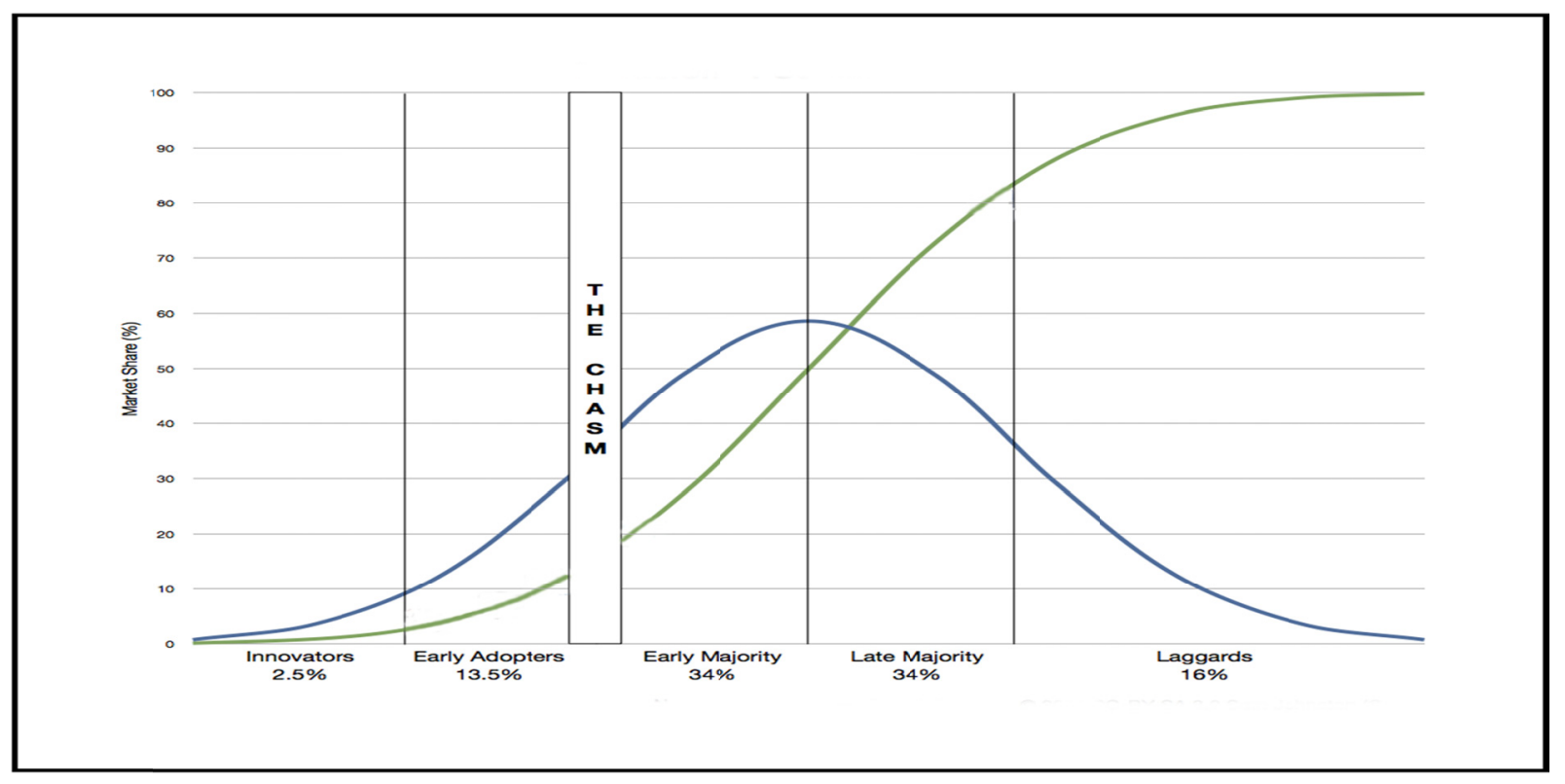

Figure 5. Position of the Chasm on Technology Adoption Curve

Source: Johnston (2011)

According to Lehman and Wiedmeryer (2011), early adopters are self motivated to use new technologies and therefore make radical changes from old technologies to new ones, whilst those in the early majority must be won over and persuaded in order for a product to have any chance of crossing Moore's chasm.

\subsubsection{Crossing the Chasm}

In order to overcome the 'chasm crisis', Moore (1991) recommends choosing one market segment (niche) that is made of customers who are able to reference each other when making buying decisions and concentrate all marketing efforts on them. This is because it will create an ongoing chain-reaction effect that will ultimately lead to a perceived market leadership (Moore, 1991). Moore (1991) identifies 4 stages for crossing the chasm, namely, targeting the point of attack, assembling an invasion force, defining the battle and launching the invasion. Targeting a specific market entails identifying a niche as the point of attack and focusing all resources on achieving the dominant leadership in that segment while assembling an invasion force means creating the whole product (finished product), by taking into consideration customer's problems, needs and solutions in their entirety and assemble relevant personnel. Defining the battle relates to creating the competition around what a pragmatist buyer would consider to be a reasonable buy, defining positioning and building this into all the company communications. Creating the competition and launching the invasion means the distribution of direct sales and support mechanisms whilst concentrating on the most efficient strategy. Launching also entails pricing products to suit the different market segments so that value-based pricing is set for visionaries, competitive-based pricing is set for pragmatists and cost-based pricing is set for conservatives.

\section{Method}

The study took a mixed method approach which was qualitative-led. At the method level, qualitative sampling methods were used where non-probability sampling techniques were used to select the samples. Convenience sampling was used to select the sample for bank and supermarket customers and purposive or judgmental sampling was used for selecting the samples for bank and supermarket managers. At the same time, questionnaires were used to collect quantitative data (Johnson, Onwuegbuzie \& Turner, 2007). At the sample level, triangulation was used through the use of different types of data sources in an effort to improve the validity of research findings. Therefore in this study, data was collected from customers, bank and supermarket managers in an attempt to reduce the likelihood of bias and misinterpretation (Sandelowski, 2000).

The study population comprised of 16 banks located in Harare and the three largest supermarkets in Zimbabwe (located in Harare) that agreed to participate in the study. Harare (the Capital City) was chosen because most head offices of these banks and supermarkets were located there and therefore the views of the participants were presumed to encompass the views of their respective banks and supermarkets countrywide. Questionnaires were used to collect data from all the three samples because questionnaires enable a lot of data to be collected in a short space of time and they were best suited for the constantly busy banking and supermarket environments (Bailey, 1987). Close-ended questions 
were used because they provided standardised data and were easier to code as the respondents were asked to select one or more of the specific categories provided by the researchers (Bailey, 1987). In this case, the respondent is often clearer about the meaning of the question which leads to less ambiguous responses.

The close-ended questions were composed of nominal scales. The nominal scales were used for labeling variables, without any quantitative value and were used to measure frequencies (Stevens, 2005; Bailey, 1987). The collected data was analyzed through the Statistical Package for the Social Sciences (SPSS) computer programme (Version 20) software database for quantitative analysis. The SCAMPER (which is an acronym for Substitute, Combine, Adapt, Modify, Put to other uses, Eliminate and Reverse) method of theory formation was used to plot the results on Moore's Technology Adoption Curve to form an infographic (Cheng, 2001). An infographic or information graph is a visualization of data, ideas or knowledge intended to convey complex information clearly by blending data and design in a manner that can be quickly comprehended and easily understood (Smiciklas, 2012). Therefore the resultant infographic (curve) showing the position of the adopted online transaction platforms on the Moore's Technology Adoption Curve was derived from a combination of Figures 2 to 5 in conjunction with the results from this study.

\section{Results}

Questionnaires were distributed to 400 bank and supermarket customers and 268 were returned giving a return rate of $67 \%$. On the other hand, 80 questionnaires were also distributed to 80 bank employees and 56 were returned giving a return rate of $70 \%$ while 45 questionnaires were distributed to supermarket employees and 31 were returned giving a return rate of $68 \%$. Thus the mean return rate for the three samples was $67.6 \%$.

Background information was gathered from the customers and it showed that there were more males than females and that the majority of the customers were in the $31-40$ age group, had a $1^{\text {st }}$ degree educational qualification and were employed in the public sector as shown in Table 1.

Table 1. Background Information for Bank and Supermarket Customers

\begin{tabular}{|c|c|c|c|c|c|c|c|}
\hline Variable & Category & & & & & & \\
\hline Gender & Male & Female & Total & & & & \\
\hline Percentage & 57 & 43 & 100 & & & & \\
\hline Age & $30 \&$ below & $31-41$ & $41-50$ & $51-66$ & $61 \&$ above & Total & \\
\hline Percentage & 35 & 56 & 8 & 1 & - & 100 & \\
\hline $\begin{array}{l}\text { Educational } \\
\text { Qualifications }\end{array}$ & 'O' Level & 'A' Level & Diploma & $1^{\text {st }}$ Degree & Masters Degree & $\mathrm{PhD}$ & Total \\
\hline Percentage & 4 & 10 & 21 & 32 & 29 & 4 & 100 \\
\hline Occupation & $\begin{array}{l}\text { Self } \\
\text { Employed }\end{array}$ & Private Sector & Public Sector & Student & Unemployed & Retired & Total \\
\hline Percentage & 9 & 28 & 50 & 11 & 1 & 1 & 100 \\
\hline
\end{tabular}

Background information was also gathered from the bank and supermarket employees and the results indicated that the majority of the bank employees were branch managers while the majority of the supermarket employees were till operation managers as shown in Table 2.

Table 2. Background Information for Bank and Supermarket Employees

\begin{tabular}{|c|c|c|c|c|c|c|c|}
\hline \multirow{2}{*}{$\begin{array}{l}\text { Variable } \\
\text { Position in Bank }\end{array}$} & \multicolumn{7}{|c|}{ Category } \\
\hline & Branch Mr & & Bank Operations M & lagers & & ICT & Total \\
\hline Percentage & & 6 & & 36 & & 18 & 100 \\
\hline Position & Branch & Assistant & Branch Accounting & Till Operations & ICT & Others & Total \\
\hline Supermarket & Managers & Managers & Managers & Managers & Managers & & \\
\hline Percentage & 10 & 13 & 16 & 26 & 16 & 19 & 100 \\
\hline
\end{tabular}

Customers were asked whether they had access to Internet services or not and the majority of them (95\%) had access to Internet services whilst only 5\% did not have access. Respondents were also asked whether they owned an ATM card or not and the majority of them (96\%) had ATM cards and only 4\% did not. When asked whether they owned a cell phone handset, all the respondents owned a handset. Further analysis showed that the majority of the respondents owned one handset each (51\%), followed by 39\% who owned two handsets and 10\% who owned 3 handsets respectively.

Customers were asked which platform they preferred to use when interacting with their banks and the majority of the participants (38\%) preferred using ATM, followed by the Banking Hall (27\%), Mobile banking (15\%), Internet banking $(10 \%)$, POS (9\%) and other (1\%) respectively as shown in Figure 6. 


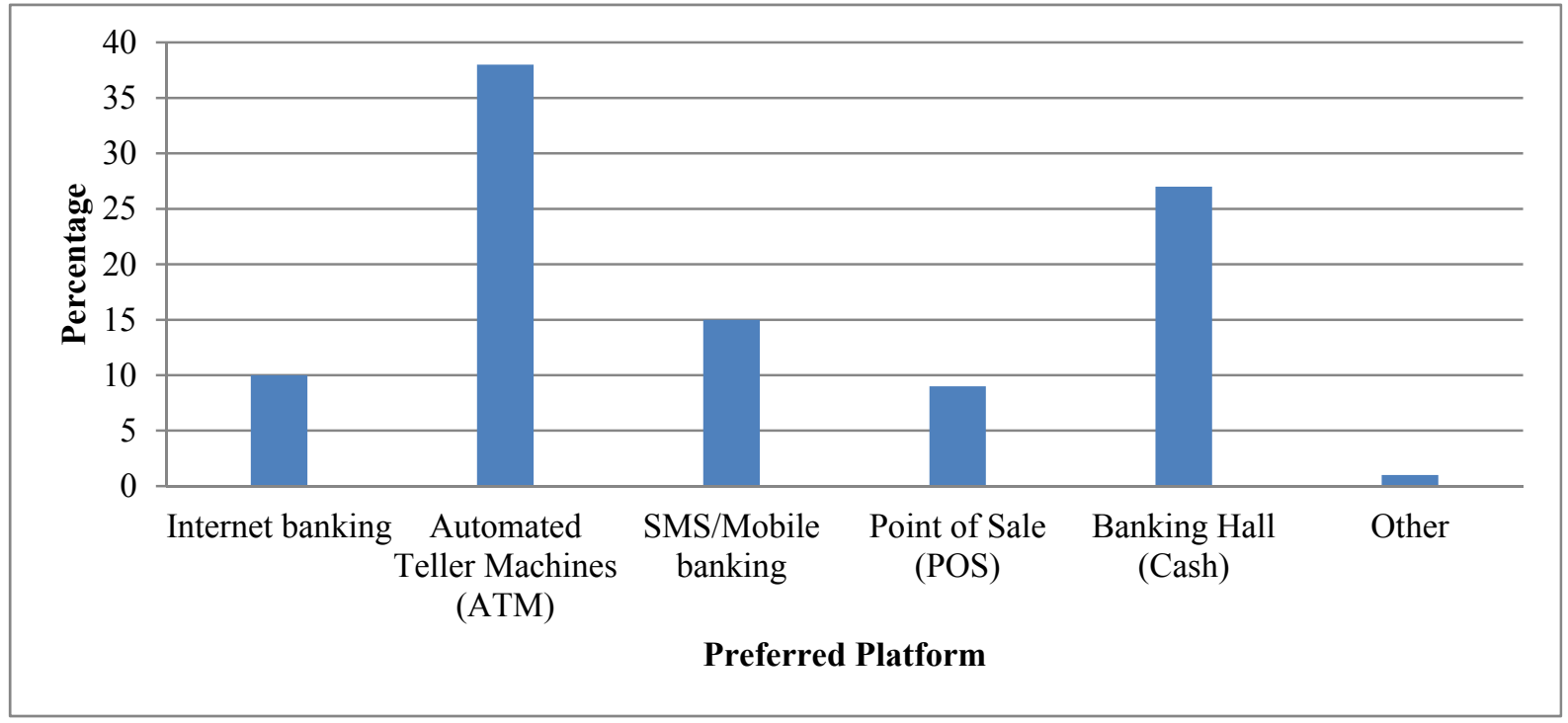

Figure 6. Customers' Preferred Platform for Interacting with bank

Respondents were asked what their preferred platform for payment when buying groceries in a Supermarket was and the majority of them (77\%) preferred using cash, followed by $20 \%$ who preferred using the ATM card, $2 \%$ who preferred using Mobile money and $1 \%$ who preferred using other modes of payments as shown in Figure 7.

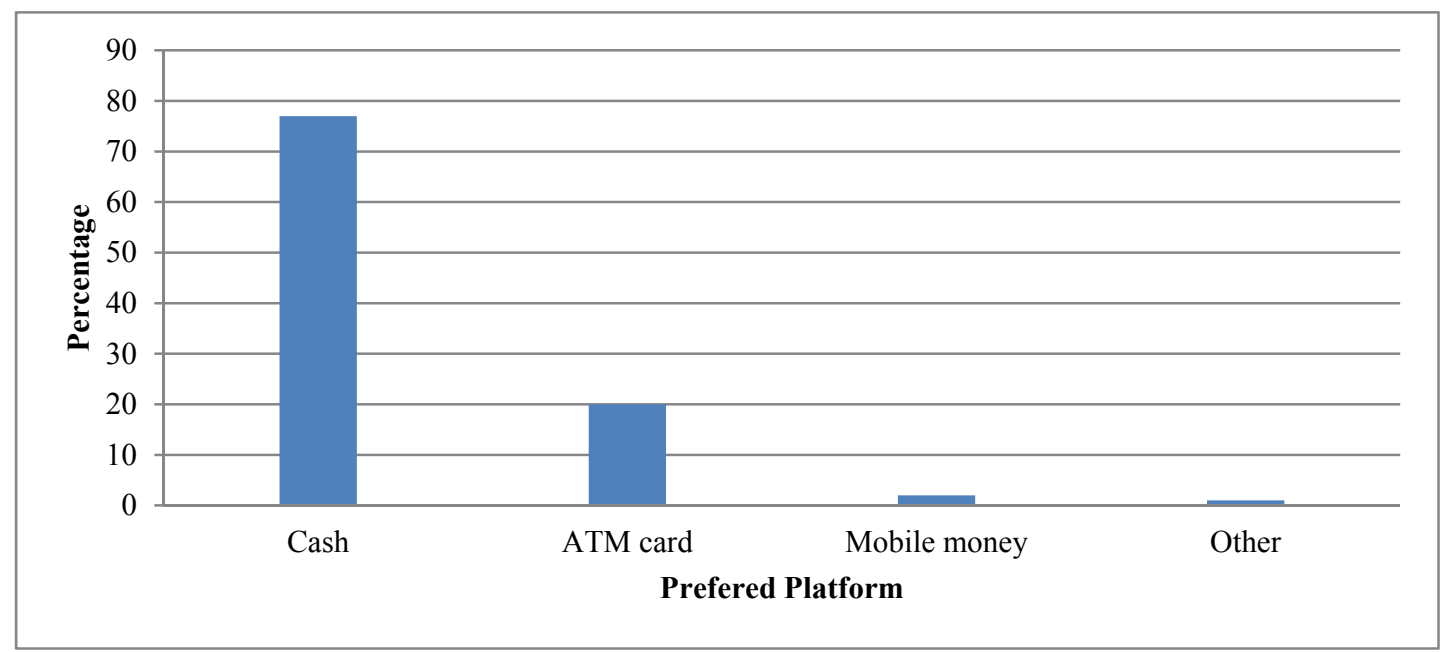

Figure 7. Preferred Platform for Payment when buying groceries by customers

Customers were asked which mobile money platforms they had registered with and the results indicated that the majority $(80 \%)$ of the respondents had registered for Ecocash, followed by Telecash (8\%) and then OneWallet (2\%). However, $10 \%$ of the respondents had not registered for any of the mobile money platforms as shown in Figure 8 . 


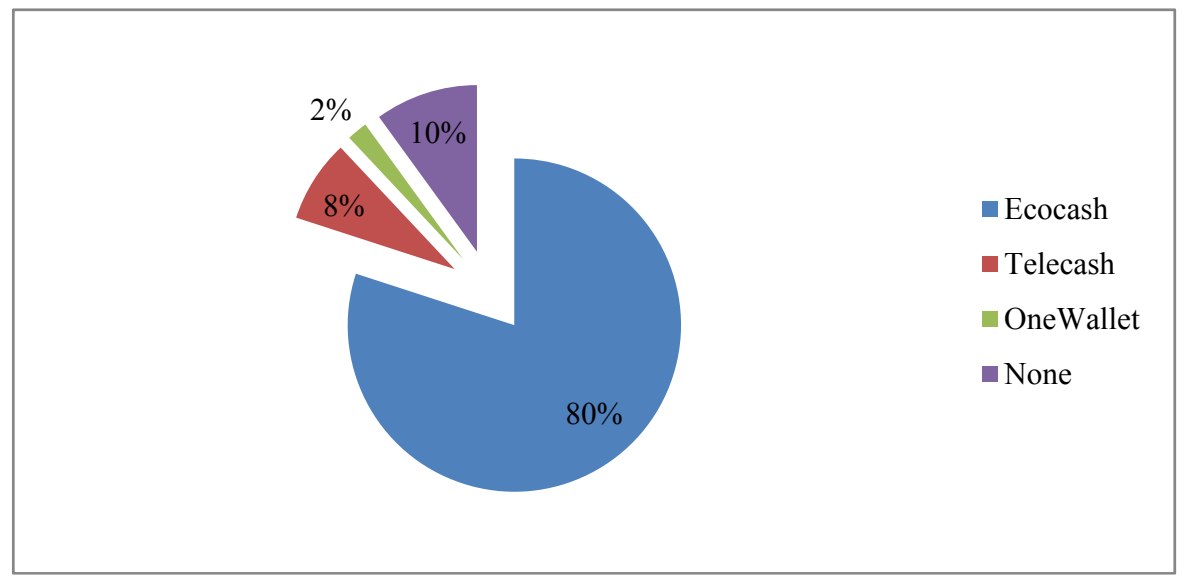

Figure 8. Mobile Money Platforms registered by customers

A cross tabulation analysis was made to find the relationship between preferred platform for interacting with customers' banks and the age of the respondents and the results indicated that all customers of the age group 61 and above preferred cash transactions through the banking hall (100\%) followed by the $51-60$ age group who preferred the banking hall $(50 \%)$ and the ATM (50\%). The majority of the $41-50$ age group preferred the ATM (55\%), followed by the Banking hall $(20 \%)$, POS (15\%) and the Internet (10\%) respectively. The majority of the $31-40$ age group preferred the ATM (41\%), followed by the Banking hall (25\%), Mobile banking (15\%), POS (11\%), Internet banking $(7 \%)$ and the other $1 \%$ preferred to use other means of interacting with their bank respectively.

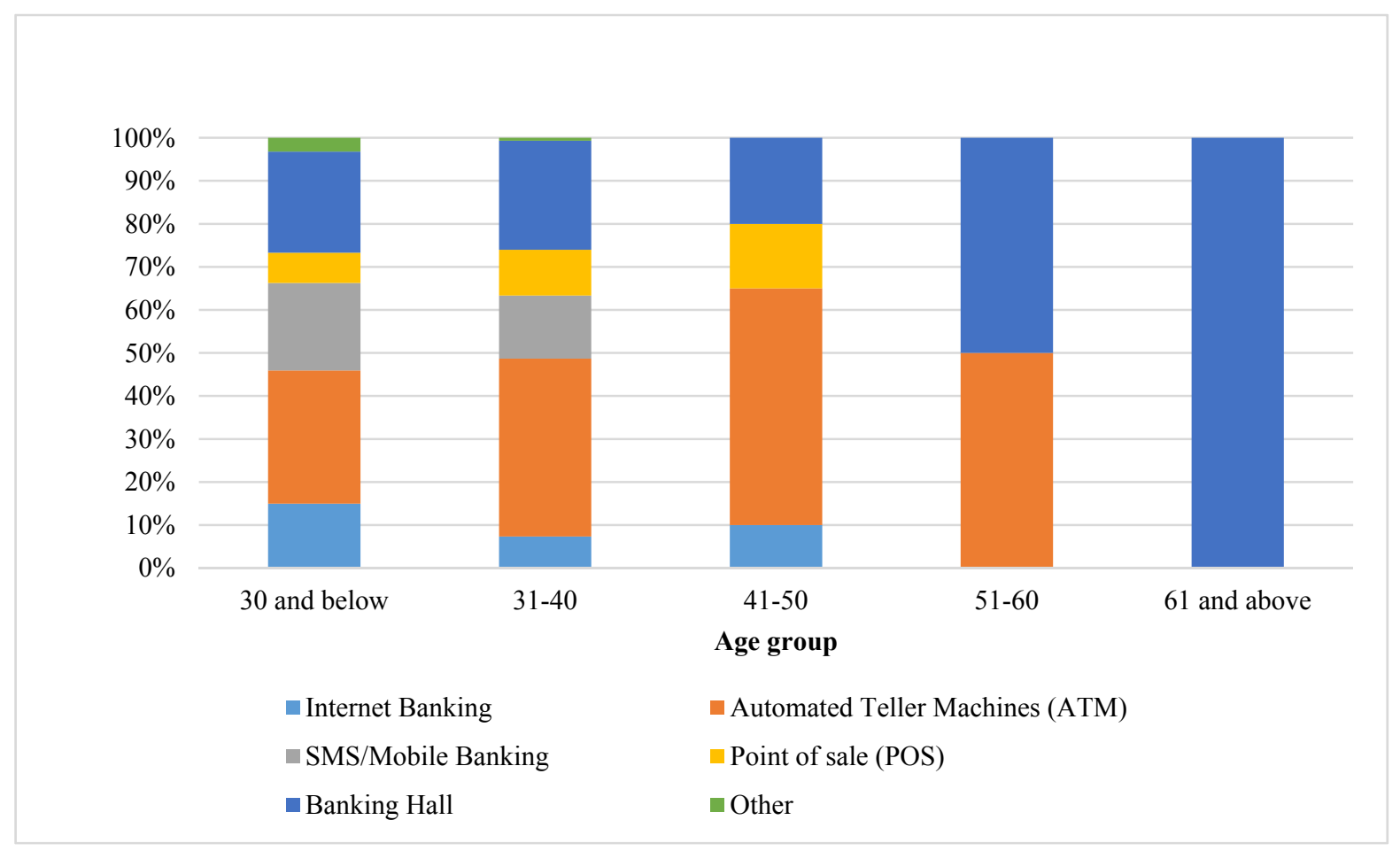

Figure 9. Relationship between Customers' Preferred Channels for interaction with Bank and age group

Further analysis of Figure 9 showed that the 61 and above age group prefers to use one channel (Banking hall/cash) whilst the $51-60$ age group prefers to use 2 channels. The ATM came out as the most preferred channel across all age groups excluding the 61 and above age group. Internet banking is preferred by those below the age of 50 but highest amongst the 30 and below age group. Mobile banking is only preferred by those of 40 years and below but is highest amongst the 30 and below age group. POS is only preferred by those of 50 years and below but highest amongst the 41 - 50 age group as shown in Figure 9. Overall, the younger generations prefer to use more channels than the older generations in their interaction with their banks.

A cross tabulation analysis was also made to find the relationship between age and the mobile money platform 
registered for by customers and the results indicated that all respondents of the 61 and above age group had not registered for any mobile money platform. Half of those in the 51-60 age group had registered for Telecash (50\%) and the other half (50\%) had not registered for any platform at all as shown in Figure 10.

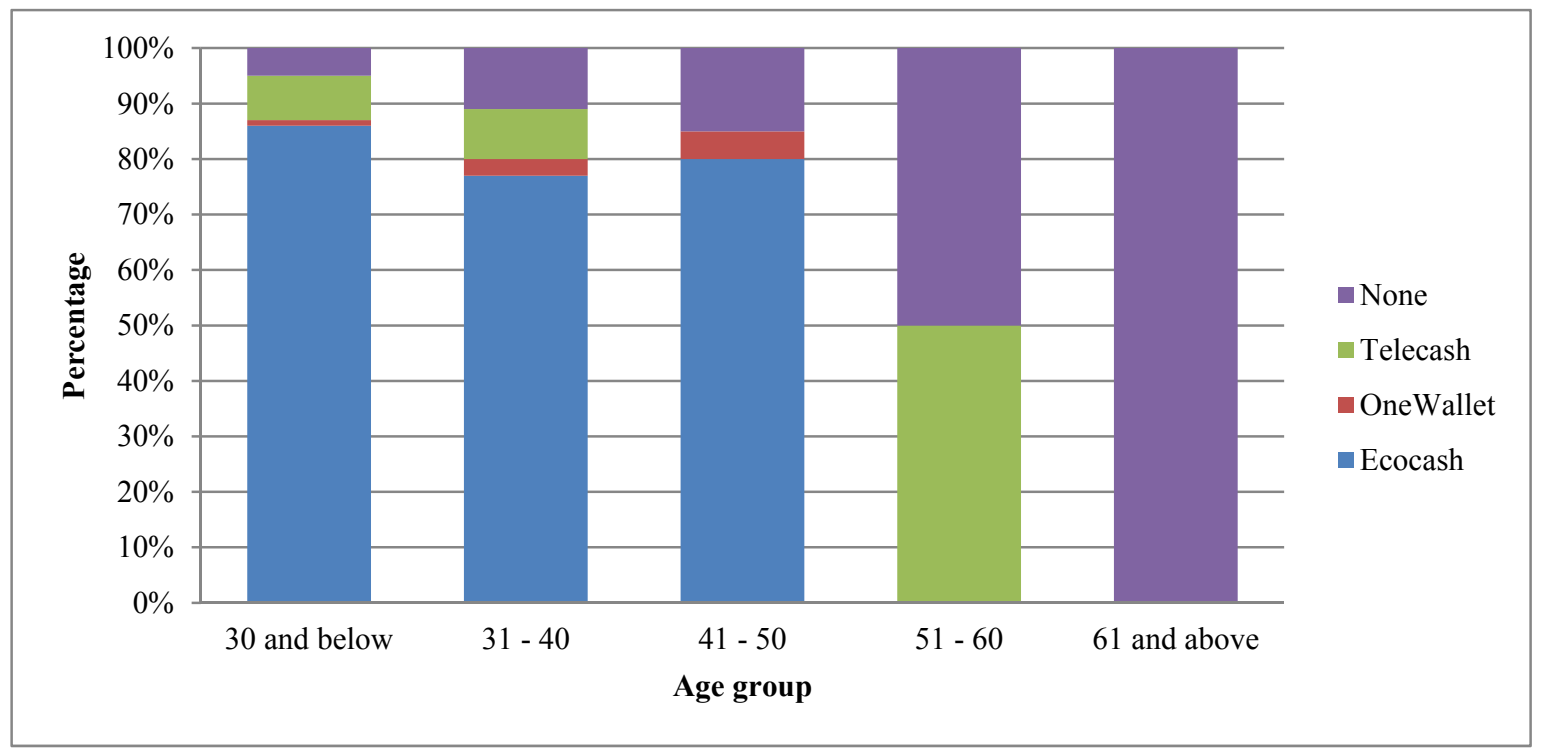

Figure 10. Relationship between Mobile money platforms registered for by Customers and age group

Those in the $41-50$ age group had mostly registered with Ecocash (80\%), and the majority of the 31 - 40 age group had registered for Ecocash (77\%). Most of those in the 30 and below age group had registered for Ecocash (86\%). Further analysis showed that older generations had registered for fewer platforms than the younger generations. Participants in all age groups who had registered (except the $51-60$ who preferred Telecash) had registered for Ecocash. Of the three platforms, One Wallet was the least registered for as shown in Figure 10.

\subsection{Analysis of Uptake of Online Transactions Platforms in Banks}

Bank employees were asked which online transactions platforms their banks had adopted and the responses indicated that most banks had adopted ATM (95\% of the respondents) followed by Internet banking (94\%) then POS (84\%) respectively as shown in Figure 11. The least adopted was Mobile banking (79\%).

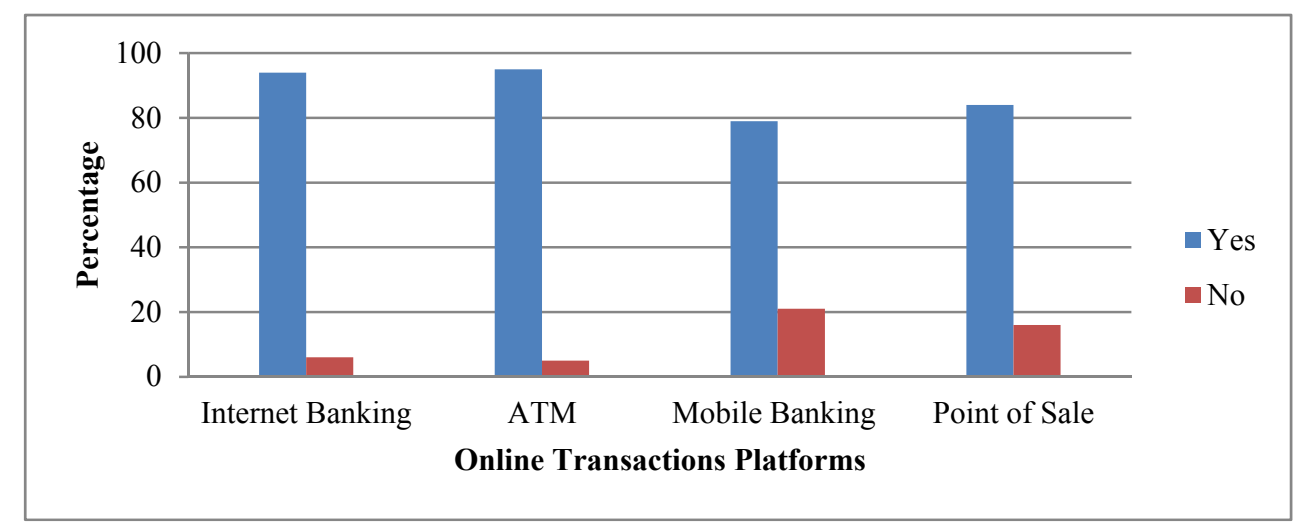

Figure 11. Adoption of Online Transactions Platforms in Banks

When asked what percentage volume of revenue was transferred through the given online transaction platforms per month, the majority of bank employees (48\%) indicated that $10 \%$ and below of their banks' percentage revenue was transacted through Internet banking followed by Mobile banking (22\%) as shown in Figure 12. The results also indicated that the highest percentage volume of revenue (over $75 \%$ ) was transferred through ATM (28\% of the respondents) followed by POS ( $27 \%$ of the respondents) respectively. 


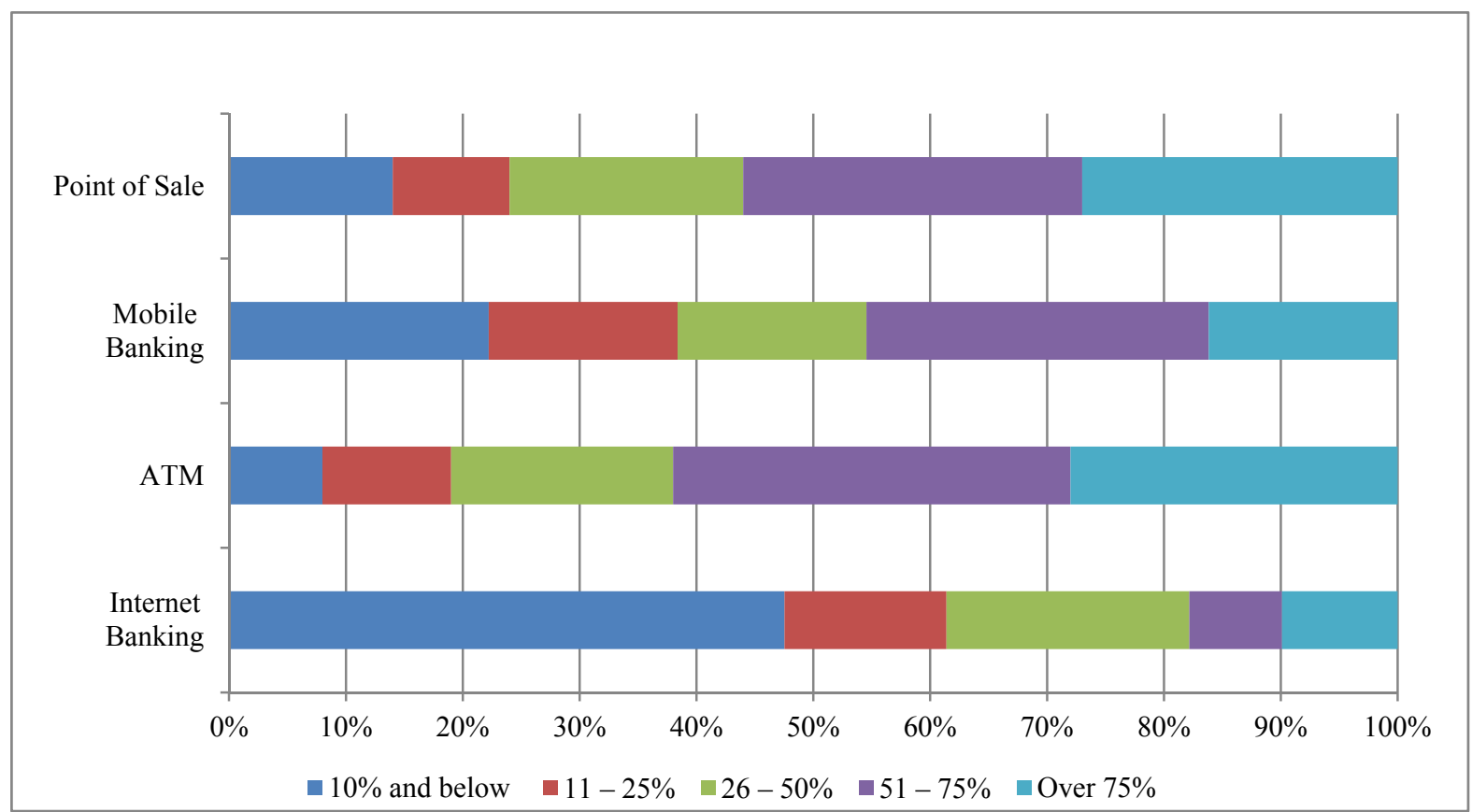

Figure 12. Volume of revenue transferred through Online Transaction Platforms per month in banks

On the whole, after computing the averages/means of percentage volumes of revenue transferred through each platform, the results indicated that the greatest volume was transferred through Internet banking (20.2\%), followed by the ATM $(20 \%)$ and Mobile banking (19.8\%) as shown in Table 3. The least volume of funds was transferred through Point of Sale (19.2\%). Finally, after computing the mean of means, it showed that only $19.8 \%$ (approximately $20 \%$ ) of the banks' revenue is transferred through online transactions per month as shown in Table 3.

Table 3. Mean volume of revenue transferred through Online Transaction platforms per month in banks

\begin{tabular}{lllllll}
\hline Online Platform & $\mathbf{1 0 \%}$ Below & $\mathbf{1 1 - \mathbf { 2 5 } \%}$ & $\mathbf{2 6 - \mathbf { 5 0 } \%}$ & $\mathbf{5 1 - \mathbf { 7 5 } \%}$ & Over 75\% & Percentage Mean \\
\hline POS & 14 & 10 & 20 & 25 & 27 & 19.2 \\
Mobile banking & 22 & 16 & 16 & 29 & 16 & 19.8 \\
ATM & 8 & 11 & 19 & 34 & 28 & 20 \\
Internet banking & 48 & 14 & 21 & 8 & 10 & 20.2 \\
Mean of Means & & & & & & 19.8 \\
\hline
\end{tabular}

\subsection{Analysis of Uptake of Online Transactions Platforms in Supermarkets}

Supermarket employees were asked which online transaction initiatives their supermarkets had adopted and all of them $(100 \%)$ indicated that their supermarkets had adopted POS while $26 \%$ indicated that their supermarkets had adopted mobile money as well to buy groceries.

When asked what percentage of their customers used POS services per month, the majority of them (42\%) indicated that most customers use $20 \%$ and below of POS services, followed by $29 \%$ who used $21-40 \%$ and $19 \%$ who used over $70 \%$ of the POS services respectively as shown in Figure 13. Very few respondents (7\% and 3\%) indicated $51-70 \%$ and $41 \%-50 \%$ of their customers used POS services respectively. Overall, after computing the average percentages of customers using POS services in supermarkets using percentages in Figure 13, the results indicated that $20 \%$ of the customers used POS to buy groceries. 


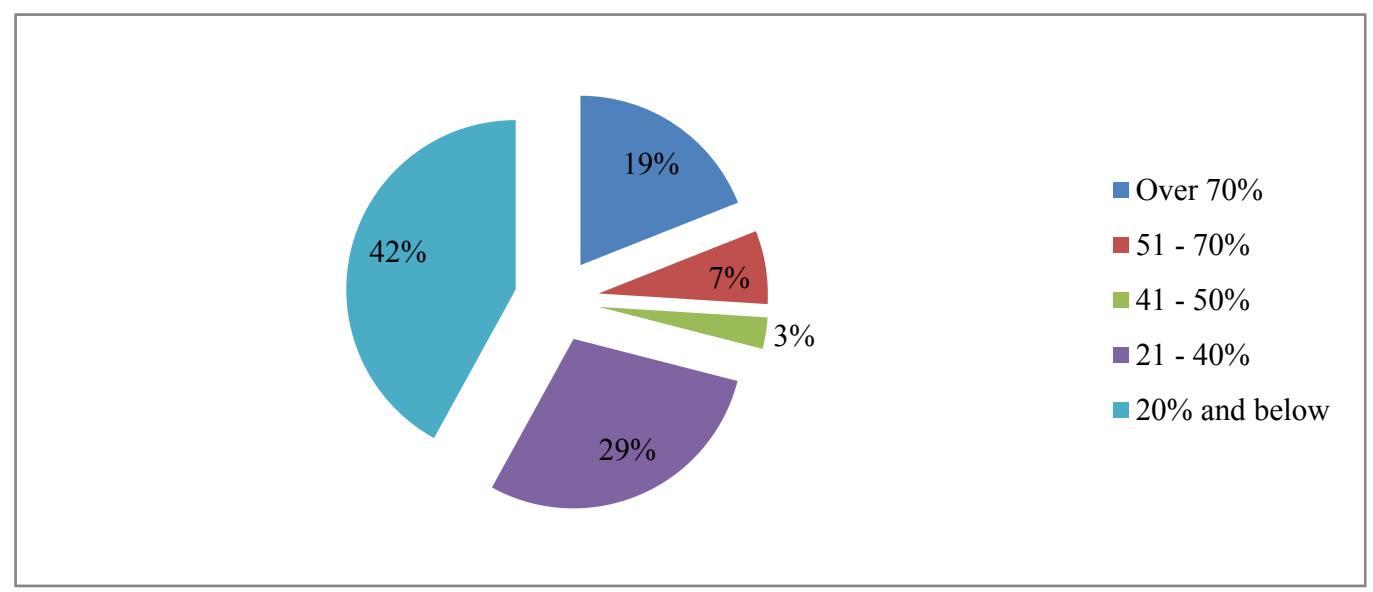

Figure 13. Percentage of customers using POS services in Supermarkets

After computing the means of the adoption rates of online transaction platforms, the results indicated that the overall adoption rates in the retail industry was 14.5 as shown in Table 4 . The adoption rate for banks was $88 \%$ and that for supermarkets was $63 \%$ giving an overall adoption rate for the retail industry (banks and supermarkets) as $75.5 \%$. Table 4 also shows that the customers have a high overall non- adoption rate $(89 \%)$ whereas the non-adoption rate for banks and supermarkets is relatively low $(24.5 \%)$ as shown in Table 4.

Table 4. Adoption Rates in the Retail Industry in Zimbabwe

\begin{tabular}{|c|c|c|c|c|c|c|c|}
\hline Transaction & $\begin{array}{l}\text { Internet } \\
\text { banking }\end{array}$ & ATM & $\begin{array}{l}\text { Mobile } \\
\text { banking }\end{array}$ & POS & $\begin{array}{l}\text { Mobile } \\
\text { Money }\end{array}$ & $\begin{array}{l}\text { Mean } \\
\text { Adoption Rate }\end{array}$ & $\begin{array}{l}\text { Non-Adoption } \\
\text { Rate }\end{array}$ \\
\hline $\begin{array}{l}\text { Adoption Rate for Bank } \\
\text { Customers }\end{array}$ & $10 \%$ & $38 \%$ & $15 \%$ & $9 \%$ & - & $18 \%$ & $82 \%$ \\
\hline $\begin{array}{l}\text { Adoption Rate for } \\
\text { Supermarket Customers }\end{array}$ & - & - & - & $20 \%$ & $2 \%$ & $11 \%$ & $89 \%$ \\
\hline Mean Rates for Customers & - & - & - & $14.5 \%$ & - & $14.5 \%$ & $85.5 \%$ \\
\hline Adoption Rate for Banks & $94 \%$ & $95 \%$ & $79 \%$ & $84 \%$ & - & $88 \%$ & $12 \%$ \\
\hline $\begin{array}{l}\text { Adoption Rate for } \\
\text { Supermarkets }\end{array}$ & - & - & - & $100 \%$ & $26 \%$ & $63 \%$ & $37 \%$ \\
\hline $\begin{array}{l}\text { Mean Rates for banks and } \\
\text { Supermarkets }\end{array}$ & & & & & & $75.5 \%$ & $24.5 \%$ \\
\hline
\end{tabular}

4.4 Position of Online Transactions on the Technology Adoption Curve

Using the SCAMPER method of theory formation, Figures 2, 3, 4, 5 and the results shown in Table 4 were combined, adapted and modified and the position of online transaction platform was plotted on the infographic technology adoption Curve shown in Figure 14. The S-curves in Figure 2 and Figure 5 were used to determine the position of online transactions on the technology adoption curve. Figure 14 shows that, Mobile money is still in the prenatal stage and is placed at the beginning of the curve at $2 \%$ market penetration and is adopted by innovators or technology enthusiasts. Internet banking is in the infancy stage and is placed just at the beginning of the chasm at $10 \%$ market penetration where early adopters or the visionaries have also adopted it. POS (14.5 market penetration), Mobile banking (at 15\% market penetration) and the ATM (at 38\% market penetration) are placed in the chasm, with POS and Mobile banking just about to reach Johnston's 16\% position of the chasm (Figure 5). Although the ATM is still in the chasm, it is about to cross it. This entails that POS, Internet banking and the ATM have been adopted by the innovators or technology enthusiasts as well as the early adopters or the visionaries.

The average adoption of online transactions in Zimbabwe is at 14.5\% (Table 4) market penetration and is indicated by the red star $(*)$ in Figure 14. This places the average adoption between the infancy stage and the child stage. Therefore, the task that Zimbabwe's retail industry has is to reach and cross the chasm for mobile money and to successfully cross the chasm for POS, Internet banking and the ATM. This entails attracting and persuading the mainstream market and subsequently reaching the vision of a cashless retail industry in Zimbabwe. 


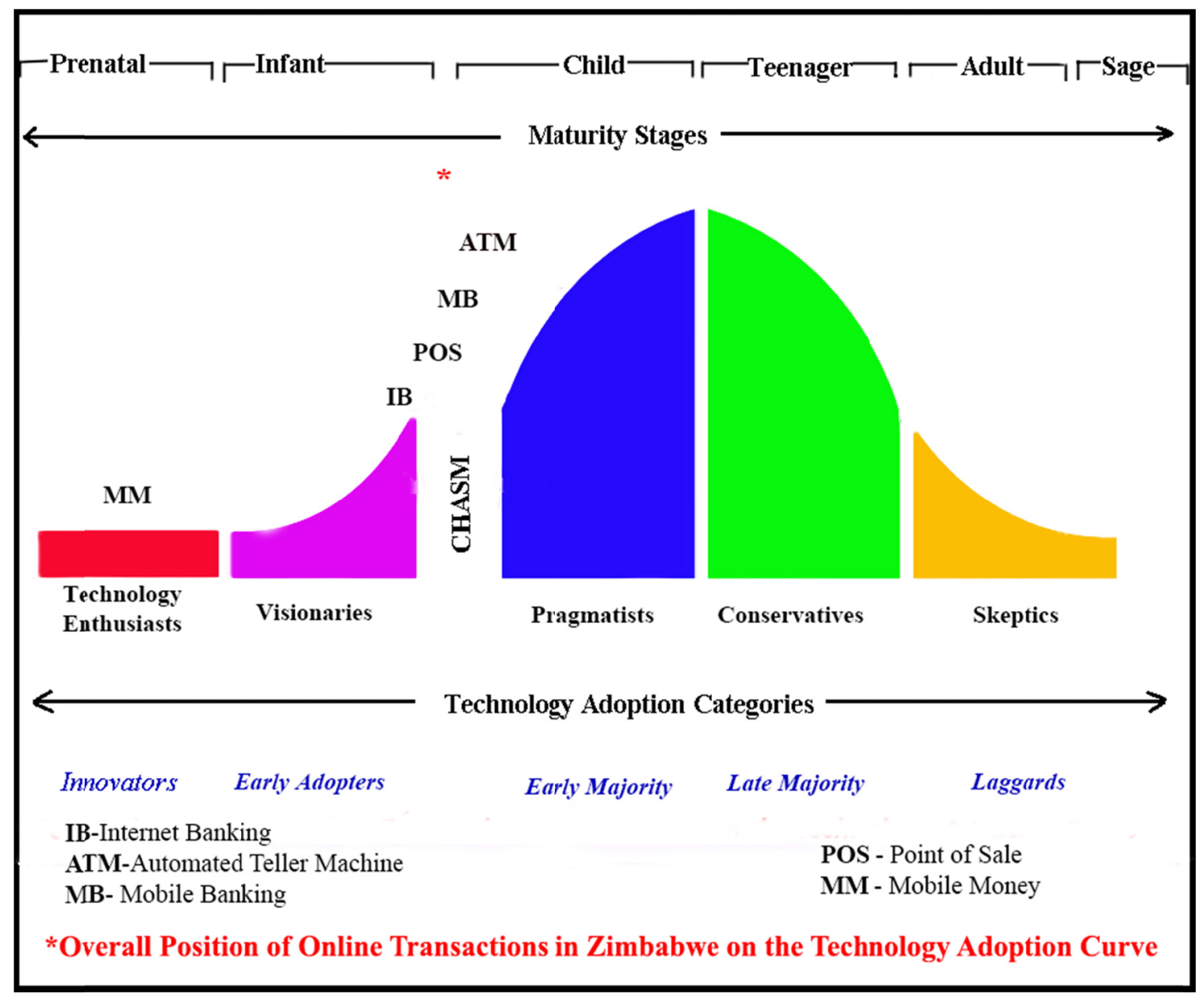

Figure 14. Positions of Online Transactions Platforms in the Retail Industry in Zimbabwe on the Technology Adoption Curve

\section{Discussion}

The majority of the customers had access to the internet and this is an indication that the potential for customers to use online transaction platforms (which are largely Internet based) was there. The majority of the customers also had ATM cards and had the potential to do online transactions with their banks and to use them for buying groceries through the POS in supermarkets. All customers owned a cell phone handset whilst some even owned 2 or 3 handsets which gave a mobile penetration of over 100\% and this is supported by Lancaster and Lange (2015) who ascertain that by 2014, mobile penetration in Zimbabwe had reached 128\% since some customers owned more than one (1) mobile cell phone. The results indicated that of the 3 Mobile Money Operators in Zimbabwe, the majority of customers had registered with Ecocash followed by Telecel and OneWallet respectively. These results are in line with Kabweza (2014) who stated that Ecocash had the largest subscribers, followed by Telecash and OneWallet respectively. The adoption of Mobile money platforms entails that customers had the means to do online transactions using them in banks and supermarkets.

The adoption rate of the ATM, Internet banking, Mobile banking and POS was generally high with an overall average adoption rate for banks at $88 \%$ (Figure 11 and Table 4). The adoption rate for POS in supermarkets was high (100\%) but they were lagging behind in adopting mobile money (26\%). This could be because mobile money was a later innovation than POS and its adoption was still going through the decision making process and had not reached the confirmation stage as shown in Figure 1. However the overall adoption in supermarkets was relatively high at $63 \%$ (Section 4.3 and Table 4). Despite this high adoption of online initiatives by banks and supermarkets, the adoption by customers was lagging behind. This is because the volume of revenue transferred/transacted through online transaction platforms per month in banks was still very low (19.8\%) as indicated in Table 3 .

With respect to customers, the adoption rates by bank customers were still low. This is because the adoption rates for Internet banking was only $10 \%$ for Internet banking, 38\% for the ATM, $15 \%$ for Mobile banking and $9 \%$ for POS (Figure 6 and Table 4). This gives a mean adoption rate of $18 \%$ for bank customers as shown in Table 4 . The adoption rate for supermarkets customers was also low at $20 \%$ for POS and 2\% for Mobile money giving a mean adoption rate of 
$11 \%$ for supermarket customers as shown in Table 4 . With reference to POS, although $20 \%$ of the customers indicated that they used their ATM cards for buying groceries with respect to the banking section on the questionnaire, $9 \%$ of them indicated that they used their cards for buying groceries with respect to supermarkets. Therefore the average adoption rate for POS customers was computed as $14.5 \%$ as shown in Table 4. Consequently, on the whole, the average adoption rate for online transactions platforms for the retail industry in Zimbabwe (banks and supermarkets) was 14.5\% (mean of $18 \%$ and $11 \%$ ) as shown in Table 4. Since the customers represent the market, therefore the 14.5\% represent the market penetration rate.

With reference to the diffusion of innovation theory, the adoption percentages by customers, banks and supermarkets entail that the individuals and organisations who had adopted the platforms as shown in Table 4 had gone through the processes of knowledge/awareness, persuasion, made a decision to adopt, implementation and confirmation because they found positive characteristic of the online transaction platforms, positive societal factors or had adopter characteristics that enabled adoption as shown in Figure 1. From Table 4 it can thus be deduced that the non adoption rate/percentage for customers $(85.5 \%)$ and for the retail industry, that is, banks and supermarkets $(24.5 \%)$ are at the various stages of the diffusion of innovation process (Figure 1) and have not yet reached the confirmation stage for various reasons. The reasons could be the characteristics of the online transaction platform, societal factors or adopter characteristics as illustrated in Figure 1.

According to Roger's Adoption categories, the adoption rates for customers derived from this study represent the various categories of adopters in the a-axis of the diagram in Figure 2. The total sample thus represents 100 market share and the results fall on the S-curve in Figure 2 and 5. Therefore, using market share percentages in Figure 5 and the adoption rates from this study, a market share of $14.5 \%$ has adopted online transaction platforms (Table 4 ). It can thus be extrapolated that Zimbabwe's retail industry has managed to capture the innovators and the early adopters (Figure 2) which are represented by the technology enthusiasts and the visionaries on Moore's Adoption Curve (Figure 3). Thus with reference to the chasm in Figure 3 and Figure 5, the average market share of $14.5 \%$ falls in Moore's chasm of technology adoption. In terms of technology adoption maturity, online transaction platforms in the retail industry in Zimbabwe are in their infant stage according to the six stages of the Maturity Model Adoption Curve shown in Figure 4.

With respect to Moore's chasm, Figure 14 entails that Internet banking has reached the chasm and is about to start crossing it whilst, POS and Mobile banking are in the chasm and the ATM is about to finish crossing the chasm. Moore (1991) argues that when a new product approaches the chasm, it is normally about $80 \%$ of what the complete finished product would look like and that is adoptable for visionaries, but pragmatists will not accept less than a $100 \%$ finished product. This is why in Zimbabwe; Telecel has been adopted by $100 \%$ of the 61 years and above age group because Telecel was the first MNO to be established in Zimbabwe. Therefore the older generations trusted it as they had enough time to process and accept it through the innovation decision process shown in Figure 1. However, in terms of buying groceries, the results entail that in Zimbabwe, mobile money platforms still need to be developed to about $80 \%$ for visionaries and subsequently the mainstream market to fully accept them. On the other hand, Internet banking, POS and Mobile banking have been developed to $80 \%$ of their capacity. However Figure 14 entails that the ATM is almost $100 \%$ developed and the early majority or pragmatists may begin to embrace it.

The results also indicated that by and large, the younger generations preferred to use more online transaction platforms than the older generations with special reference to those in the 61 and above age group who preferred to transact using cash in the banking hall as shown in Figure 9. At the same time, Figure 10 also indicated that the younger generations also registered for more mobile money platforms than the older generations with special reference to those in the 61 and above age group who had registered for none. The results are in line with Rogers (1995) who argues that innovators are the youngest in age and are technically savvy with deep application domain expertise and are thus willing to venture into new technology as they are risk tolerant. The results are also supported by Moore's technology adoption curve where technology enthusiasts are described as the younger generation who embrace things immediately because they are attracted to disruptive innovation per se as they want to try out new things and see how they work (Moore, 1991). The results also indicated that Rogers' early adopters are also part of the market share that has been captured. This is especially true to banks and supermarket employees who may be opinion leaders in their banks as they hold leadership roles in the retail industry. The high adoption rates in banks and supermarkets could be explained by that the managers put their stamp of approval on new ideas/products (online initiatives) by adopting them (Rogers, 1995). In congruence with this study's results and Rogers (1995), Moore (1991) spells out that visionaries look to leapfrog their competition by being the first to leverage the innovation and are therefore willing to take extra risks to get a major advantage. Thus the adoption of $14.5 \%$ of the market share indicates that bank and supermarket managers could be visionaries in their organisations as they see that online transaction platforms could give them a competitive urge in the domestic and international market.

On another note, the results indicated that the retail industry in Zimbabwe has captured the early market and still has the 
task of capturing the mainstream market as indicated by Rogers (1991) and Martinez (2010) in Figure 3. The early market is indicated by the $14.5 \%$ in Table 4 and the mainstream market being the $85.5 \%$ (yet to be captured). The laggards or skeptics are the older generation who still prefer to use cash in the banking hall according to Figure 9 and also are not registered for Mobile money as shown in Figure 10. This is supported by Rogers (1995) and May (2014) who add on to say that skeptics simply want to have as little to do with disruptive innovations as possible and therefore only adopt a strong product whose documentation is robust.

\section{Conclusions}

The study set out to explore the current extent of adoption of online transaction platforms in the retail industry in Zimbabwe. The paper thus concludes that ATM, Internet banking, Mobile banking and POS have been adopted by most banks and supermarkets; however, adoption of Mobile money in supermarkets is still low. On the other hand adoption of online transactions by customers is still relatively low at a market penetration of $14.5 \%$. The study also sought to find out where Zimbabwe's adoption of online transaction platforms in the retail industry is on the Technology adoption curve. In this respect, this paper thus concludes that in terms of market penetration, the early market (innovators or technology enthusiasts and the early adopters or the visionaries) has been penetrated on Moore's chasm in the Technology Adoption Curve. In terms of the Maturity Model Adoption Curve the retail industry is towards the end of the infancy stage. Overall, the online transactions are in Moore's chasm on the technology adoption curve.

\section{Recommendations}

The paper recommends customers to adopt and use online transactions in order to prepare for the future technological society. Banks and supermarkets are also urged to embark on niche marketing where strategies to attract the mainstream market to use online transactions are employed. This could be through continuous development of value based products that are user friendlier for the older generations. At the same time, banks and supermarkets are urged to develop more products and marketing strategies for the future generations in an effort to prepare for a cashless society. It is hoped that the results of this study have bridged the literature and theory gap on online transactions platforms in Zimbabwe and will be used as a foundation for further studies.

The major limitation of this study could be that the results may be limited to online transaction platforms in banks and supermarkets only. Therefore, further research could be undertaken to test the results of this study and to explore the position of other online transactions platforms in various environments in Zimbabwe, in the Diaspora and internationally. This could be done in an effort to provide ideas that would lead towards following global technological trends of online financial transacting.

\section{Acknowledgements}

The authors express their gratitude to the National University of Science and Technology Research Board for providing funding for this study.

\section{References}

Bailey, K. D. (1987). Methods of Social Research (3rd ed.). London: Macmillan. https://doi.org/10.1080/20421338.2016.1156839

Bara, A. (2016). Diffusion and adoption of bank financial innovation in Zimbabwe: An external factor analysis. African Journal of Science, Technology, Innovation and Development, 8(4), 357-368. https://doi.org/10.1080/20421338.2016.1156839

Baten, M. A., \& Kamil, A. (2010). E-Banking of Economical Prospects in Bangladesh. Journal of Internet Banking and Commerce, 15(2), 1-10. Retrieved from http://www.arraydev.com/commerce/jibc/

Bernardo, M. (2013). Point of Sale. Retrieved from http://www.slideshare.net/yuri56/point-of-sale-29179086

Chang, H. (2010). A New Perspective on Twitter Hashtag Use: Diffusion of Innovation Theory. State University of New York. https://doi.org/10.1002/meet.14504701295

Cheng, V. M. Y. (2001). Enhancing Creativity of Elementary Science Teachers-a preliminary study. Asia-Pacific Forum on Science Learning and Teaching, 2(2), 1-23. Retrieved from https://www.ied.edu.hk/apfslt/download/v2_issue2_files/chengmy/chengmy.pdf

Chikoko, L., \& Mangwendeza, P. (2012). Financial inclusion by Zimbabwean commercial banks in a liquidity constrained environment. Journal of Economics and International Finance, 4(10), 252-259. https://doi.org/10.5897/JEIF12.075

Confederation of Zimbabwe Industries. (2014). 2014 CZI Manufacturing Sector Survey Report. Retrieved from http://www.czi.co.zw/images/Presentations/2014.pdf 
Dhliwayo, C. L. (2014). A Sound Financial Sector - Heart Beat Of Growth. Paper presented at 2014 Annual Conference of the Institute of Administration and Commerce, Kariba, Zimbabwe. Retrieved from http://www.iac.co.zw/Docs/syllabus/IACPresentationinKariba.docx

Dube, C., \& Gumbo, V. (2017). Adoption and Use of Information Communication Technologies in Zimbabwean Supermarkets. Journal of Applied Economics and Finance, 4(1), 84-92. https://doi.org/10.11114/aef.v4i1.1860

Dube, T., Chitura, T., \& Runyowa, L. (2009). Adoption and use of Internet Banking in Zimbabwe: An exploratory Study. Journal of Internet Banking and Commerce, 14(1). Retrieved from http://www.arraydev.com/commerce/jibc/2009-04/Dube\%20etal.pdf

Dube, T., Njanike, K., Manomano, C., \& Chiriseri, L. (2011). Adoption and use of SMS/Mobile banking services in Zimbabwe, An Exploratory Study. Journal of Internet Banking and Commerce, 16(2), 1-15. Retrieved from http://www.arraydev.com/commerce/JIBC/2011-08/tdube\%20manuscript.pdf

Eckerson, W. (2009). Maturity Model Adoption Curve - Six Stages. The Data Warehousing Institute: Education and Research. Retrieved from http://www.eurim.org.uk/activities/ig/voi/03-01-06_Executive_Series_Assessing_Your_BI_Maturity.pdf

Ernst \& Young, E. (2009). Mobile Money: An overview for global telecommunications operators. Retrieved from http://www.ey.com/Publication/vwLUAssets/Mobile_Money./\$FILE/

Gilbert, L., \& Hewitt, J. (2013). Online Transaction Processing. Retrieved from http://searchdatacenter.techtarget.com/definition/OLTP

Goyal, K. A., \& Joshi, V. (2011). A Study of Social and Ethical issues in Banking Industry. International Journal of Economics, 2(5), 49-57. $\quad$ Retrieved from http://www.ijeronline.com/documents/volumes/Vol\%202\%20issue\%205/ijer20110205SO\%285\%29.pdf

Hadadi, N. A., Otaif, H. M., Faqihi, A. Y., \& Al-ahmadi, W. (2006). E-Banking - Benefits and Challenges. (Bachelor of Business Administration Degree dissertation, Jazan University, Jazan, Saudi Arabia). Retrieved from http://colleges.jazanu.edu.sa/GirlsCampus/bac/Documents/10.pdf

Hossain, M., \& Bari, R. (2006). Understanding of ATM (Automated Teller Machine) in Bangladesh. (Bachelor of Computer Science and Engineering Dissertation, BRAC University, Dhaka, Bangladesh). Retrieved from http://dspace.bracu.ac.bd/bitstream/handle/10361/479/Understanding+of+ATM+in+Bangladesh.pdf?sequence=1

Jenkins, B. (2008). Developing Mobile Money Ecosystems. Retrieved from https://www.hks.harvard.edu/m-rcbg/papers/jenkins_mobile_money_summer_008.pdf

Johnson, R. B., Onwuegbuzie, A. J., \& Turner, A. L. (2007). Toward a Definition of Mixed Methods Research. Journal of Mixed Methods Research, 1(2), 112-133. https://doi.org/10.1177/1558689806298224

Johnston, S. (2011). Infographic: Diffusion of Social Networks. Retrieved from https://samj.net/2011/11/10/infographic-diffusion-of-social-networks-facebook-twitter-linkedin-and-google/

Kabanda, G. (2014). Technology Affordances and Diffusion for Mobile Connectivity and Applications in Zimbabwe. International Journal of Emerging Technology and Advanced Engineering, 4(6), 13-23. Retrieved from http://www.ijetae.com/files/Volume4Issue6/IJETAE_0614_02.pdf

Kabweza, L. S. M. (2014). NetOne by the numbers: 2.7 mil subscribers, 200k OneWallet subs, $\$ 105 \mathrm{M}$ revenue. TechZim Technologies. 24 June. Retrieved from www.techzim.co.zw/2014/06/netone-by-the-numbers/

Kaminski, R. N. (2011). Diffusion of Innovation Theory. Canadian Journal of Nursing Informatics, 6(2). Retrieved from http://cjni.net/journal/?p=1444

Lancaster, H., \& Lange, P. (2015). Zimbabwe Telecoms Mobile and Broadband Market Insights and Statistics. Retrieved from www.budde.com/au/research/zimbabwe-telecoms

Lehman, M., \& Wiedmeryer, W. (2011). Closing the Convergence Gap. Zanthus Corporation Publications, white paper (August). Retrieved from http://www.zanthus.com/publications/articles/2011/closing_the_convergence_gap/docs/Closing_the_Convergence _Gap_Whitepaper.pdf

Makiwa, P. J., \& Steyn, R. (2016). ICT adoption and Use in Zimbabwean SMEs. Proceedings of the IST - Africa 2016 Conference Proceedings. Durban, South Africa. R https://doi.org/10.1109/ISTAFRICA.2016.7530576

Mangudya, C. L. (2014). Reserve Bank of Zimbabwe Monetary Statement Policy: Back to Basics: Setting the tone for Zimbabwe's Economic Recovery, July 2014. Retrieved from www.rbz.co.zw 
Martinez, C. (2010). Technology Adoption Life Cycle. Retrieved from http://carlosmartinezt.com/2010/06/technology-adoption-life-cycle

May, E. (2014). How To Cross The Tech Chasm. Innovation Excellence. Retrieved from http://www.innovationexcellence.com/blog/2014/06/05/how-to-cross-the-tech-chasm/

Meerapur, A. (2014). Online Transaction Processing (OLTP). Retrieved from http://www.studymode.com/essays/Online-Transaction-Processing-Oltpthe-Following-Is-65509396.html.

Moore, G. (2015). The 5 Customer Segments of Technology Adoption. Retrieved from https://ondigitalmarketing.com/learn/odm/foundations/5-customer-segments-technology-adoption/

Moore, G. A. (1991). Crossing the Chasm: Marketing and Selling High-Tech Products to Mainstream Customers. (Revised ed.). New York: Harper Collins Publishers.

Moore, G. A. (2003). Crossing the Chasm: Marketing and Selling High-Tech Products to Mainstream Customers. (3rd ed.). New York: Harper Collins Publishers.

Mudzingwa, P., \& Kabote, F. (2014). Exploring Modern Technology Adoption in Zimbabwe's Beauty Therapy Industry. Journal of Humanities and Social Science. 19(5), 44-48. Retrieved from http://iosrjournals.org/iosr-jhss/papers/Vol19-issue5/Version-4/H019544448.pdf

Muza, K. (2013, July, 23). Where is Zimbabwe's technology? Why? TechZim. Retrieved from http://www.techzim.co.zw/2013/07/where-is-zimbabwes-technology-why/

Nabih, M. I., Bloem, N. J. G., \& Poiesz, T. B. C. (1997). Conceptual Issues in the Study of Innovation Adoption Behavior. Advances in Consumer Research, 24, 190-196. Retrieved from http://acrwebsite.org/volumes/8041/volumes/v24/NA-24

Rahmani, Z., Tahvildari, A., Honarmand, H., Yousefi, H., \& Daghighi, M. S. (2012). Mobile Banking and its Benefits. Arabian Journal of Business and Management Review, 2(5), 37-40. https://doi.org/10.12816/0002266

Reisman, A. (2006). Transfer of Technologies: 'A Cross-disciplinary Taxonomy'. The International Journal of Management Science, $\quad 33, \quad 189-202 . \quad$ Retrieved from http://www.bpj.ir/images/content/\%D8\%A7\%D9\%86\%D8\%AA\%D9\%82\%D8\%A7\%D9\%84\%20\%D9\%81\%D9 \%86\%D8\%A7\%D9\%88\%D8\%B1\%D9\%8A.pdf

Rogers, E. M. (1995). Diffusion of innovations. (4th ed.). New York: Free Press.

Rogers, E. M. (2003). Diffusion of innovations. (5th ed.). New York: Free Press.

Sahin, I. (2006). Detailed Review of Rogers' Diffusion of Innovations Theory and Educational Technology-Related Studies Based on Rogers' Theory. The Turkish Online Journal of Educational Technology. 5(2) Retrieved from http://files.eric.ed.gov/fulltext/ED501453.pdf

Sandelowski, M. (2000). Focus on Research Methods Combining Qualitative and Quantitative Sampling, Data Collection, and Analysis Techniques in Mixed-Method Studies. Research in Nursing \& Health, (23) 246-255. https://doi.org/10.1002/1098-240X(200006)23:3<246::AID-NUR9>3.0.CO;2-H

Smiciklas, M. (2012). The Power of Infographics: Using Pictures to Communicate and Connect with Your Audiences. Indiana: Pearson Education Inc. Retrieved from http://ptgmedia.pearsoncmg.com/images/9780789749499/samplepages/0789749491.pdf

Steeneken, F., \& Ackley, D. (2012). A complete Model of the Supermarket Business. Retrieved from http://www.bptrends.com/publicationfiles/01-03-2012-ART-Supermarket\%20Article-steeneken-Ackley\%2011122 6.pdf

Stevens, G. (2005). Nominal, Ordinal and Interval data. Retrieved from http://www.psychlotron.org.uk/resources/stats/AS_ANY_stats_levelsofmeasurement.pdf

Tsokota, T., \& von Solms, R. (2013). ICT and the turning - around of the Zimbabwean Economy. Proceedings of the International Conference on ICT for Africa pp.20-23, Harare, Zimbabwe. Retrieved from http://www.ictforafrica.org/attachments/section/4/ict4africa2013_submission_19.pdf

ZimSwitch Technologies. (2013). Online Payments. Retrieved from http://www.zimswitch.co.zw/

\section{Copyrights}

Copyright for this article is retained by the author(s), with first publication rights granted to the journal.

This is an open-access article distributed under the terms and conditions of the Creative Commons Attribution license which permits unrestricted use, distribution, and reproduction in any medium, provided the original work is properly cited. 